\title{
Electrochemical performance of reversible molten carbonate fuel cells
}

\author{
Lan Hu*, Ivan Rexed, Göran Lindbergh, Carina Lagergren
}

Applied Electrochemistry, School of Chemical Science and Engineering, KTH Royal Institute of Technology, SE-100 44

Stockholm, Sweden

\section{A R T I C L E I N F O}

Article history:

Received 4 December 2013

Received in revised form

18 February 2014

Accepted 22 February 2014

Available online 25 March 2014

\section{Keywords:}

Molten carbonate electrolysis cell

$\mathrm{Ni}$ electrode

$\mathrm{NiO}$ electrode

Reversible molten carbonate fuel cell

\begin{abstract}
A B S T R A C T
The electrochemical performance of a state-of-the-art molten carbonate cell was investigated in both fuel cell (MCFC) and electrolysis cell (MCEC) modes by using polarization curves and electrochemical impedance spectroscopy (EIS). The results show that it is feasible to run a reversible molten carbonate fuel cell and that the cell actually exhibits lower polarization in the MCEC mode, at least for the short-term tests undertaken in this study. The Ni hydrogen electrode and the NiO oxygen electrode were also studied in fuel cell and electrolysis cell modes under different operating conditions, including temperatures and gas compositions. The polarization of the Ni hydrogen electrode turned out to be slightly higher in the electrolysis cell mode than in the fuel cell mode at all operating temperatures and water contents. This was probably due to the slightly larger masstransfer polarization rather than to charge-transfer polarization according to the impedance results. The $\mathrm{CO}_{2}$ content has an important effect on the Ni electrode in electrolysis cell mode. Increasing the $\mathrm{CO}_{2}$ content the $\mathrm{Ni}$ electrode exhibits slightly lower polarization in the electrolysis cell mode. The NiO oxygen electrode shows lower polarization loss in the electrolysis cell mode than in the fuel cell mode in the temperature range of $600-675^{\circ} \mathrm{C}$. The impedance showed that both charge-transfer and mass-transfer polarization of the $\mathrm{NiO}$ electrode are lower in the electrolysis cell than in the fuel cell mode.

Copyright @ 2014, Hydrogen Energy Publications, LLC. Published by Elsevier Ltd. All rights
\end{abstract} reserved.

\section{Introduction}

Hydrogen and syngas $\left(\mathrm{H}_{2}+\mathrm{CO}\right)$ are today considered as important fuels in future energy systems. Hydrogen is a promising clean energy carrier for a future zero-carbon economy [1], and syngas is the raw material for synthetic hydrocarbon fuels produced by the Fischer-Tropsch synthesis technology [2]. However, these fuels are traditionally produced from fossil fuels and natural gas reforming [3]. Due to the limited fossil fuel sources, present high oil prices and environmental considerations, there is a growing interest in high-temperature electrolysis cell technology for producing hydrogen and syngas, such as the molten carbonate electrolysis cell (MCEC) and the solid oxide electrolysis cell (SOEC). An advantage of high-temperature electrolysis is the reduction of applied voltage due to favorable thermodynamic and kinetic conditions when compared to low-temperature electrolysis [4]. A further advantage is that a variety of renewable energy sources such as solar energy, wind power or nuclear power,

\footnotetext{
* Corresponding author. Tel.: +468 7908244 .

E-mail address: lanhu@kth.se (L. Hu). 
and waste heat from high-temperature industrial processes can be used to supply the power and heat required for hightemperature electrolysis.

The MCEC typically operates at about $650^{\circ} \mathrm{C}$, which means that the MCEC will consume less heat to reach the operating temperature than the SOEC. When a MCEC is operated in reverse, it operates as a molten carbonate fuel cell (MCFC) to generate electricity. Today MCFC technology has reached a level of maturity enough for commercialization in various countries such as the USA, Japan, South Korea, Italy and Germany [5]. In terms of scale of installed power generation units, the MCFC is the leader among all fuel cell technologies, for example in total more than $100 \mathrm{MW}$ has been installed in about 60 different places worldwide [6,7].Therefore, the socalled reversible molten carbonate fuel cell (RMCFC) can be regarded as a dual energy converter that operates as an electrolysis cell to produce fuel gases and as a fuel cell to produce electricity; this could improve the efficiency of the system and increase the economic benefits.

Studies on high-temperature water electrolysis for hydrogen production have been carried out since the early 1980s but have been limited to SOEC technology [8]. During these 30 years, water electrolysis by SOEC technology has achieved much progress, for example when regarding electrode and electrolyte materials, electrochemical performance and durability and modeling of SOEC and systems [9]. Lately researchers have focused not only on SOEC for hydrogen production, but also on co-electrolysis of $\mathrm{H}_{2} \mathrm{O}$ and $\mathrm{CO}_{2}$ to generate syngas $\left(\mathrm{H}_{2}+\mathrm{CO}\right)$. Mogensen et al. [10-12] reported that it is possible to electrolyze $\mathrm{CO}_{2}$ and $\mathrm{H}_{2} \mathrm{O}$ during coelectrolysis to produce a mixture of $\mathrm{H}_{2}$ and $\mathrm{CO}$ at operating temperatures ranging from 750 to $850^{\circ} \mathrm{C}$. They also presented that the area specific resistances (ASR) of the solid oxide cells were higher in electrolysis cell than in fuel cell mode in this temperature range. When it comes to MCEC research, only a few studies are done until now. Kaplan et al. [13,14] reported the conversion of $\mathrm{CO}_{2}$ to $\mathrm{CO}$ by using a cell with a molten electrolyte mixture of lithium carbonate and lithium oxide at 850-900 ${ }^{\circ} \mathrm{C}$. The electrodes were graphite (anode) and titanium (cathode) and not conventional MCFC electrodes (Nibased materials), and the working temperature was much higher than that of the MCFC system. So far the performance and durability of RMCFC is not clear and the effect on electrode materials of operating the cell both as an electrolyzer and a fuel cell is also unknown.

In this work, state-of-the-art MCFC components were used to operate the reversible molten carbonate fuel cell. The electrochemical performance of the cell was compared in MCFC and MCEC modes. The polarization loss and the impedance of the Ni hydrogen electrode and the NiO oxygen electrode were also investigated in both modes under varying operating conditions, including operating temperature and gas composition.

\section{Experimental}

Experimental data were obtained from the laboratory cell unit with a geometrical electrode area of $3 \mathrm{~cm}^{2}$. The state-of-theart components used in the study were provided by Ansaldo
Fuel Cells, Italy. The hydrogen electrode consists of porous $\mathrm{Ni}-\mathrm{Cr}$ alloy and the oxygen electrode consists of porous nickel, oxidized and lithiated in situ. The electrodes are separated by a porous $\mathrm{LiAlO}_{2}$ matrix, which also supports the electrolyte, a eutectic mixture of $62 / 38 \mathrm{~mol} \% \mathrm{Li}_{2} \mathrm{CO}_{3} / \mathrm{K}_{2} \mathrm{CO}_{3}$. Two reference electrodes (Au wires with a $33 / 67 \% \mathrm{O}_{2} / \mathrm{CO}_{2}$ gas mixture) are placed in separate chambers filled with the same electrolyte as in the cell. They are connected to the cell through a capillary with a gold plug. A schematic drawing of the laboratory cell is shown in Fig. 1 [15].

Standard gas mixtures consisting of $64 / 16 / 20 \% \mathrm{H}_{2} / \mathrm{CO}_{2} / \mathrm{H}_{2} \mathrm{O}$ and $15 / 30 / 55 \% \quad \mathrm{O}_{2} / \mathrm{CO}_{2} / \mathrm{N}_{2}$ were used for the $\mathrm{Ni}$ hydrogen electrode and the $\mathrm{NiO}$ oxygen electrode, respectively. In the experiments the $\mathrm{H}_{2} \mathrm{O}$ content in the fuel gas was controlled by the temperature of the water in the humidifier. The flow rate of the dry $\mathrm{H}_{2} / \mathrm{CO}_{2}$ mixture was held at approximately $150 \mathrm{ml} \mathrm{min}^{-1}$. The gas flow rate for the oxygen electrode was also about $150 \mathrm{ml} \mathrm{min}^{-1}$, while the reference gases had a flow rate of $20 \mathrm{ml} \mathrm{min}^{-1}$. All the gases used in the experiments were certified gas mixtures from AGA Gas AB, Sweden.

The electrochemical performances of the full cell and individual electrodes were measured by steady-state polarization curves and electrochemical impedance spectroscopy (EIS). The polarization curves were performed in potentiostatic steps by using a Solartron Interface SI1287 supported by CorrWare software. To separate the ohmic losses from other types of polarization, the current interrupt technique was used [16]. It was automatically controlled by Corrware and the shortest duration of a current interrupt was $27 \mu$ s. In all the polarization curves plotted below, the positive current density refers to fuel cell mode and the negative current density refers to electrolysis cell mode.

For the electrochemical impedance measurements Solartron frequency response analyzer 1255 and Solartron Interface SI1287 were used. The frequency spectra were recorded at three different operating conditions, including open circuit voltage (OCV), fuel cell and electrolysis cell modes. These measurements were run potentiostatically in the frequency range $10 \mathrm{mHz}-10 \mathrm{kHz}$ with an amplitude of $10 \mathrm{mV}$.

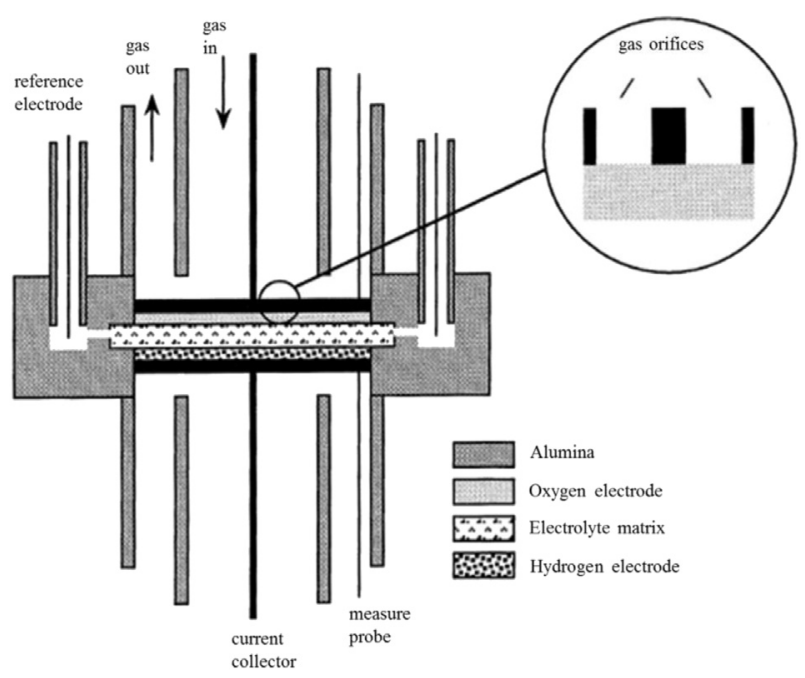

Fig. 1 - Schematic drawing of the laboratory cell unit [15]. 


\section{Results and discussion}

\section{Electrochemical performance of the reversible MCFC}

Fig. 2 shows polarization curves, with and without iRcorrection, of the cell in MCFC and MCEC modes at $650{ }^{\circ} \mathrm{C}$ with standard gas mixtures. The continuity of the polarization curves, observed close to OCV shifting from fuel cell to electrolysis cell mode, showed that it was feasible to operate the molten carbonate cell reversibly. Moreover, the cell exhibited better performance in MCEC mode than in MCFC mode. As shown in Table 1 , the total cell resistances $\left(R_{\text {tot }}\right)$, calculated from the slope of the curves without iR-correction, were 1.096 and $0.894 \Omega \mathrm{cm}^{2}$ in MCFC and MCEC modes, respectively. Also the polarization resistance $\left(R_{p}\right)$ estimated from the slope of the $i R$ correction curves showed a lower value in MCEC mode $\left(0.584 \Omega \mathrm{cm}^{2}\right)$ than in MCFC mode $\left(0.781 \Omega \mathrm{cm}^{2}\right)$. Both the $R_{\text {tot }}$ and the $R_{p}$ values were lower in MCEC mode than in MCFC mode, which showed that the cell operated better in electrolysis cell mode. At the same time, the ohmic losses of the cells were similar at $0.31 \Omega \mathrm{cm}^{2}$, under these reversible operating conditions, indicating that running the molten carbonate fuel cell reversibly did not affect the properties of the electrode materials nor the ionic conductivity in the electrolyte, at least not in this short-term test.

\section{Electrochemical performance of the Ni hydrogen electrode}

Influence of operating temperature

Fig. 3 shows iR-corrected polarization curves of the $\mathrm{Ni}$ hydrogen electrode at different operating temperatures with standard gases. In this temperature range from 600 to $675^{\circ} \mathrm{C}$, the $\mathrm{Ni}$ electrode showed an asymmetrical behavior for hydrogen oxidation $\left(\mathrm{H}_{2}+\mathrm{CO}_{3}^{2-} \rightarrow \mathrm{H}_{2} \mathrm{O}+\mathrm{CO}_{2}+2 e^{-}\right)$and water electrolysis $\left(\mathrm{H}_{2} \mathrm{O}+\mathrm{CO}_{2}+2 e^{-} \rightarrow \mathrm{H}_{2}+\mathrm{CO}_{3}^{2-}\right)$. Using a constant polarization loss of $|50| \mathrm{mV}$ at $600,625,650$ and $675^{\circ} \mathrm{C}$, the fuel cell current densities were $0.23,0.26,0.27$ and $0.31 \mathrm{~A} \mathrm{~cm}^{-2}$, while the electrolysis cell current densities were $-0.22,-0.24$, -0.25 and $-0.26 \mathrm{~A} \mathrm{~cm}^{-2}$, respectively. These values show that

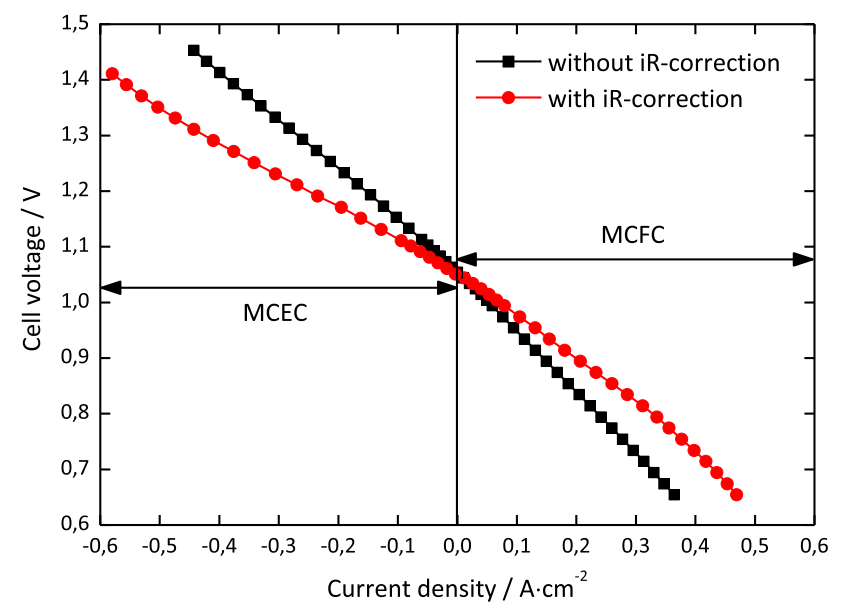

Fig. 2 - Polarization curves for the cell in MCFC and MCEC modes, working at $650{ }^{\circ} \mathrm{C}$ with standard gas mixtures.
Table 1 - Analysis of total cell resistance $\left(R_{\text {tot }}\right)$ and polarization resistance $\left(R_{p}\right)$ from the slope of the curves, without and with iR-correction, in Fig. 2. The ohmic resistance $R_{\Omega}$ is calculated as: $R_{\text {tot }}-R_{p}$.

\begin{tabular}{lccc} 
Operating modes & $\begin{array}{c}R_{\text {tot }} \\
\left(\Omega \cdot \mathrm{cm}^{2}\right)\end{array}$ & $\begin{array}{c}R_{p} \\
\left(\Omega \mathrm{cm}^{2}\right)\end{array}$ & $\begin{array}{c}R_{\Omega} \\
\left(\Omega \mathrm{cm}^{2}\right)\end{array}$ \\
\hline MCFC mode & 1.096 & 0.781 & 0.315 \\
MCEC mode & 0.894 & 0.584 & 0.31 \\
\hline
\end{tabular}

the Ni electrode performed better for hydrogen oxidation than for water electrolysis, due to higher polarization losses in the latter mode. In Table 2, the $R_{p}$ values for fuel cell and electrolysis cell mode at all measured temperatures are shown. Higher temperatures favored the performance of the Ni electrode in both fuel cell and electrolysis cell modes, as expected.

In Fig. $4(\mathrm{a}-\mathrm{d})$, the corresponding electrochemical impedance results for the $\mathrm{Ni}$ electrode are shown in three different operating modes, OCV, fuel cell and electrolysis cell modes. An overpotential versus OCV of $+0.05 \mathrm{~V}$ and $-0.05 \mathrm{~V}$ was applied on the Ni electrode to simulate fuel cell and electrolysis cell modes, respectively, and the solid symbols in the figures are referring to some specific frequencies. From the spectra it can be observed that the ohmic loss of the Ni electrode, evaluated from the intercept with the $X$-axis at the high frequency (to the left in the Nyquist plots), was slightly higher in electrolysis cell mode for all temperatures. That may be due to redistribution of electrolyte in the cell after running in electrolysis mode. For all temperatures the $\mathrm{Ni}$ electrode exhibited higher total impedance in electrolysis cell mode than in OCV and fuel cell modes, which is consistent with the results from the polarization curves discussed above. The Nyquist plots in Fig. 4 clearly show the existence of two arcs in these three operating modes, the first arc in the high-frequency region (at about $10 \mathrm{~Hz}-10 \mathrm{kHz}$ ) and the second one in the low-frequency region (at about $0.01 \mathrm{~Hz}-10 \mathrm{~Hz}$ ). The high-frequency arc is of about the same size in OCV, fuel cell and electrolysis cell modes, whilst the Ni electrode exhibits a larger low-frequency arc in electrolysis cell mode than in fuel cell mode. The size of the high-frequency arc corresponds to the charge-transfer

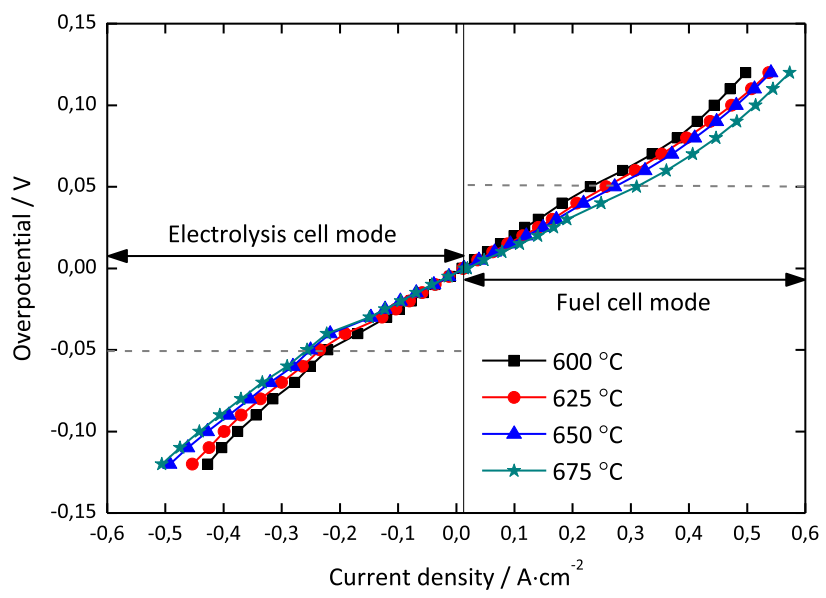

Fig. 3 - iR-corrected polarization curves for the Ni electrode in fuel cell and electrolysis cell modes at operating temperatures from 600 to $675^{\circ} \mathrm{C}$. 
Table 2 - Polarization resistance $\left(R_{p}\right)$ of the Ni electrode calculated from the slope of the iR-corrected curves at different operating temperatures in Fig. 3.

\begin{tabular}{lcc} 
Temperature & $\begin{array}{c}R_{p} \text { in fuel cell } \\
\text { mode } \\
\left(\Omega \mathrm{cm}^{2}\right)\end{array}$ & $\begin{array}{c}R_{p} \text { in electrolysis } \\
\text { cell mode } \\
\left(\Omega \mathrm{cm}^{2}\right)\end{array}$ \\
\hline $600{ }^{\circ} \mathrm{C}$ & 0.233 & 0.266 \\
$625^{\circ} \mathrm{C}$ & 0.222 & 0.249 \\
$650^{\circ} \mathrm{C}$ & 0.219 & 0.234 \\
$675^{\circ} \mathrm{C}$ & 0.207 & 0.226 \\
\hline
\end{tabular}

polarization and the size of the low-frequency arc corresponds to the mass-transfer polarization for the Ni electrode [17]. The ohmic loss, charge-transfer polarization and mass-transfer polarization calculated from the impedance spectra in Fig. 4 are shown in Table 3. The Ni electrode showed almost the same charge-transfer resistance for hydrogen production and water electrolysis, at each measured temperature. When increasing the cell temperature the charge-transfer resistance of the Ni electrode decreased, as expected, while the mass transfer resistance was more or less unaffected. This behavior supports that the high-frequency arc refers to the chargetransfer reaction. The total impedance at the Ni electrode is larger in electrolysis mode than in fuel cell mode, which is mainly caused by a higher mass-transfer resistance in electrolysis cell mode. An explanation for this difference may be the composition of the standard fuel gas used, in where the hydrogen content, being a reactant in fuel cell mode, is higher in concentration than both water and carbon dioxide, being reactants in electrolysis mode. A better comparison of the two operation modes would probably be obtained if all the components of the gas had similar concentrations. Thus, the influence of gas composition is further examined below.

\section{Influence of gas compositions}

Fig. 5 shows the effect of water content on the polarization of the Ni electrode for hydrogen oxidation and water electrolysis. The fuel gases were $72 / 18 / 10 \%, 64 / 16 / 20 \%$ and $56 / 14 / 30 \% \mathrm{H}_{2} /$ $\mathrm{CO}_{2} / \mathrm{H}_{2} \mathrm{O}$ and the operating temperature was $650{ }^{\circ} \mathrm{C}$. As shown in Fig. $5(\mathrm{a})$, the increase of water from $10 \%$ to $30 \%$ had no or only very small effect on the polarization loss of the Ni electrode in fuel cell mode. However, in electrolysis cell mode the $\mathrm{Ni}$ electrode polarization decreased gradually with increasing water content, at least for overpotential larger than $40 \mathrm{mV}$. According to the impedance spectra in Fig. 5(b), it is obvious that the increase in water content had no effect on the ohmic resistance and kinetics of the Ni electrode. However the size of the low-frequency arc decreased. Since water is a reactant in electrolysis cell mode, it makes sense that the mass-transfer resistance decreases with the increase in water content. Having more equal amounts of water and hydrogen in the gas would probably lead to similar total impedance for both modes, since the difference in impedance is caused by mass transport and not electrode kinetics.

Next, the effect of $\mathrm{CO}_{2}$ content on the electrochemical performance of the Ni electrode was investigated, as shown in Fig. 6. The fuel gas consisted of different amounts of $\mathrm{CO}_{2}$ ranging from $20 \%$ to $40 \%, 20 \% \mathrm{H}_{2} \mathrm{O}$ and $\mathrm{H}_{2}$ as balance. Although doubling the $\mathrm{CO}_{2}$ content from $20 \%$ to $40 \%$, the iR- corrected polarization curves (Fig. 6(a)) showed no effect on the performance of the Ni electrode in the fuel cell mode. However, in the electrolysis cell mode the performance of the $\mathrm{Ni}$ electrode improved significantly as the percentage of $\mathrm{CO}_{2}$ increases from $20 \%$ to $30 \%$, while showing a smaller improvement when changing from $30 \%$ to $40 \% \mathrm{CO}_{2}$. For all $\mathrm{CO}_{2}$ contents, the current densities at the constant overpotential of $50 \mathrm{mV}$ were almost $0.3 \mathrm{~A} \mathrm{~cm}^{-2}$ for the fuel cell mode, and at the same overpotential in the electrolysis cell mode they were
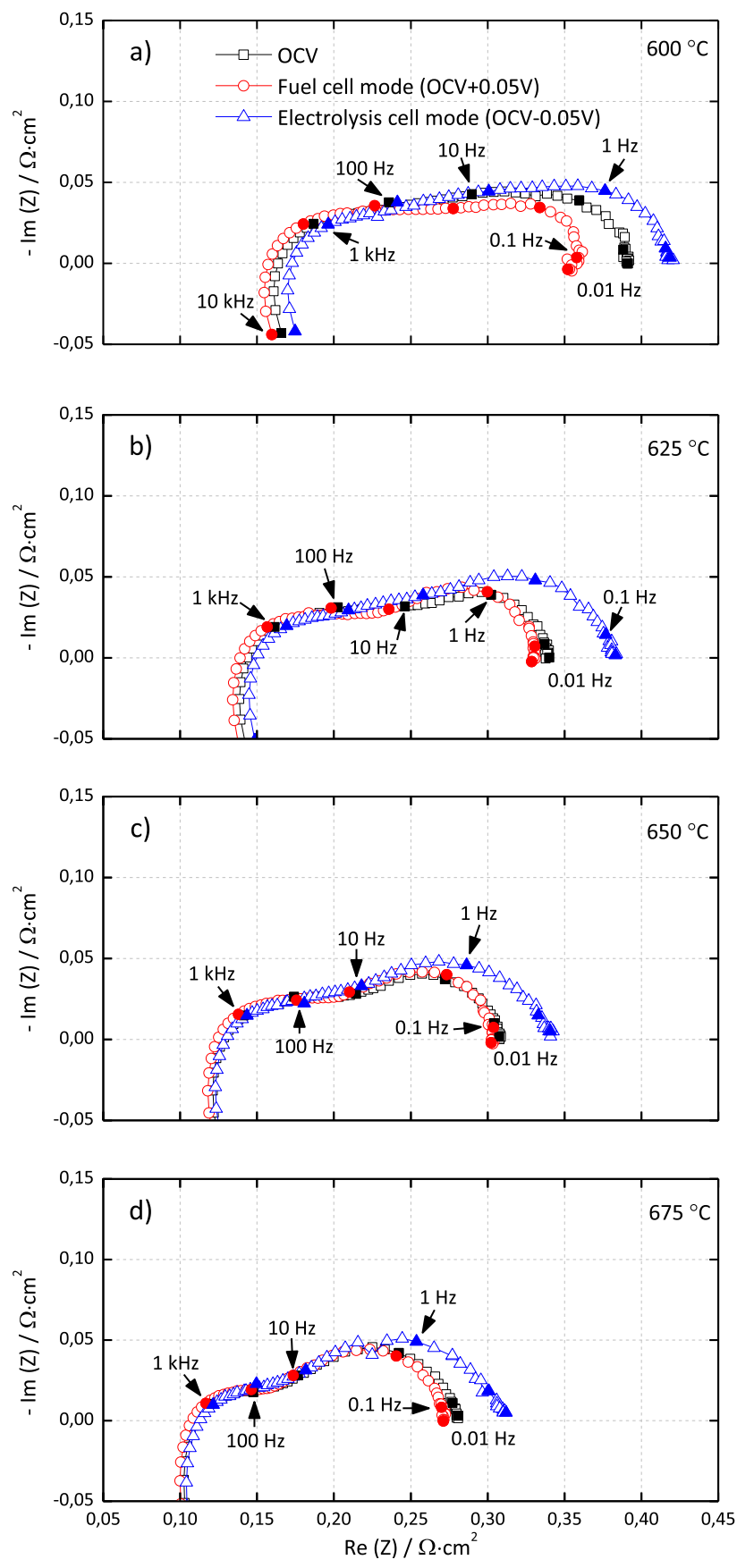

Fig. 4 - Electrochemical impedance spectra of the Ni electrode in OCV, fuel cell and electrolysis cell modes at different operating temperatures, a) $600{ }^{\circ} \mathrm{C}$, b) $625^{\circ} \mathrm{C}$, c) $650{ }^{\circ} \mathrm{C}$ and d) $675^{\circ} \mathrm{C}$. The solid symbols refer to some specific frequencies. 
Table 3 - Analysis of the electrochemical impedance spectra for the Ni electrode at different operating temperatures in Fig. 4.

\begin{tabular}{|c|c|c|c|c|c|}
\hline Resistance & Operating modes & $600^{\circ} \mathrm{C}$ & $625^{\circ} \mathrm{C}$ & $650^{\circ} \mathrm{C}$ & $675^{\circ} \mathrm{C}$ \\
\hline Ohmic loss & OCV & 0.164 & 0.144 & 0.129 & 0.112 \\
\hline \multirow{2}{*}{$\left(\Omega \mathrm{cm}^{2}\right)$} & Fuel cell & 0.157 & 0.139 & 0.125 & 0.109 \\
\hline & Electrolysis cell & 0.173 & 0.151 & 0.131 & 0.113 \\
\hline Charge-transfer polarization & $\mathrm{OCV}$ & 0.126 & 0.103 & 0.086 & 0.065 \\
\hline \multirow[t]{2}{*}{ (10 $\mathrm{Hz}$ to high frequency) $\left(\Omega \mathrm{cm}^{2}\right)$} & Fuel cell & 0.121 & 0.097 & 0.085 & 0.065 \\
\hline & Electrolysis cell & 0.128 & 0.107 & 0.087 & 0.068 \\
\hline Mass-transfer polarization & $\mathrm{OCV}$ & 0.101 & 0.094 & 0.093 & 0.104 \\
\hline$(0.01 \mathrm{~Hz}-10 \mathrm{~Hz})$ & Fuel cell & 0.074 & 0.093 & 0.092 & 0.098 \\
\hline$\left(\Omega \mathrm{cm}^{2}\right)$ & Electrolysis cell & 0.118 & 0.125 & 0.123 & 0.131 \\
\hline
\end{tabular}

$-0.25,-0.29$ and $-0.31 \mathrm{~A} \mathrm{~cm}^{-2}$ with increasing $\mathrm{CO}_{2}$ content. The increase in $\mathrm{CO}_{2}$ content to $40 \%$ showed that the absolute value of the current density was higher in electrolysis cell than in fuel cell mode at the same overpotential $(50 \mathrm{mV})$ ). , i.e. a lower polarization was obtained for the Ni electrode in electrolysis cell when the fuel gas contains as much as $40 \%$ $\mathrm{CO}_{2}$, even though water content is still $20 \%$.

The impedance results of the Ni electrode in Fig. 6(b and c) and, in agreement with the results from the polarization curves, show more or less constant performance in fuel cell mode regardless of the $\mathrm{CO}_{2}$ content. But the polarization loss in the electrolysis cell mode varies. As shown in Table 4 changes in $\mathrm{CO}_{2}$ content only marginally impacted on the
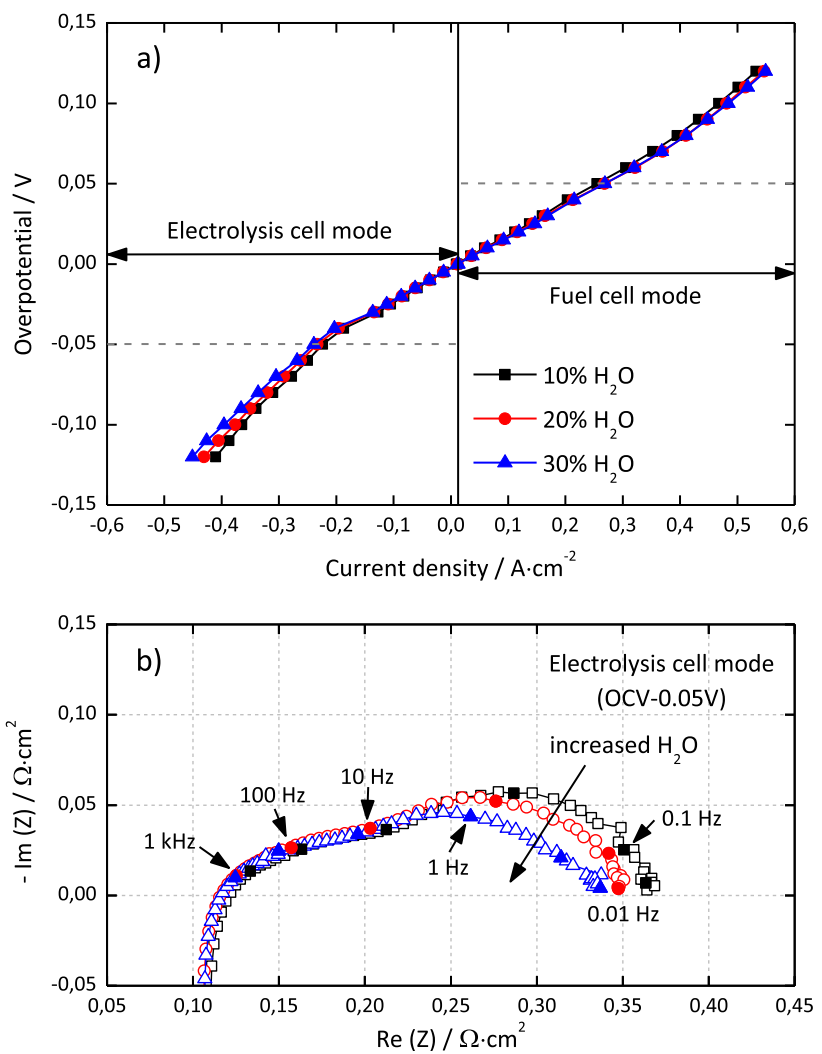

Fig. 5 - The performance of the Ni electrode at $650{ }^{\circ} \mathrm{C}$ at different percentages of $\mathrm{H}_{2} \mathrm{O}$. a) iR-corrected polarization curves and b) electrochemical impedance spectra of the $\mathrm{Ni}$ electrode in electrolysis cell mode. The solid symbols in b) refer to some specific frequencies.
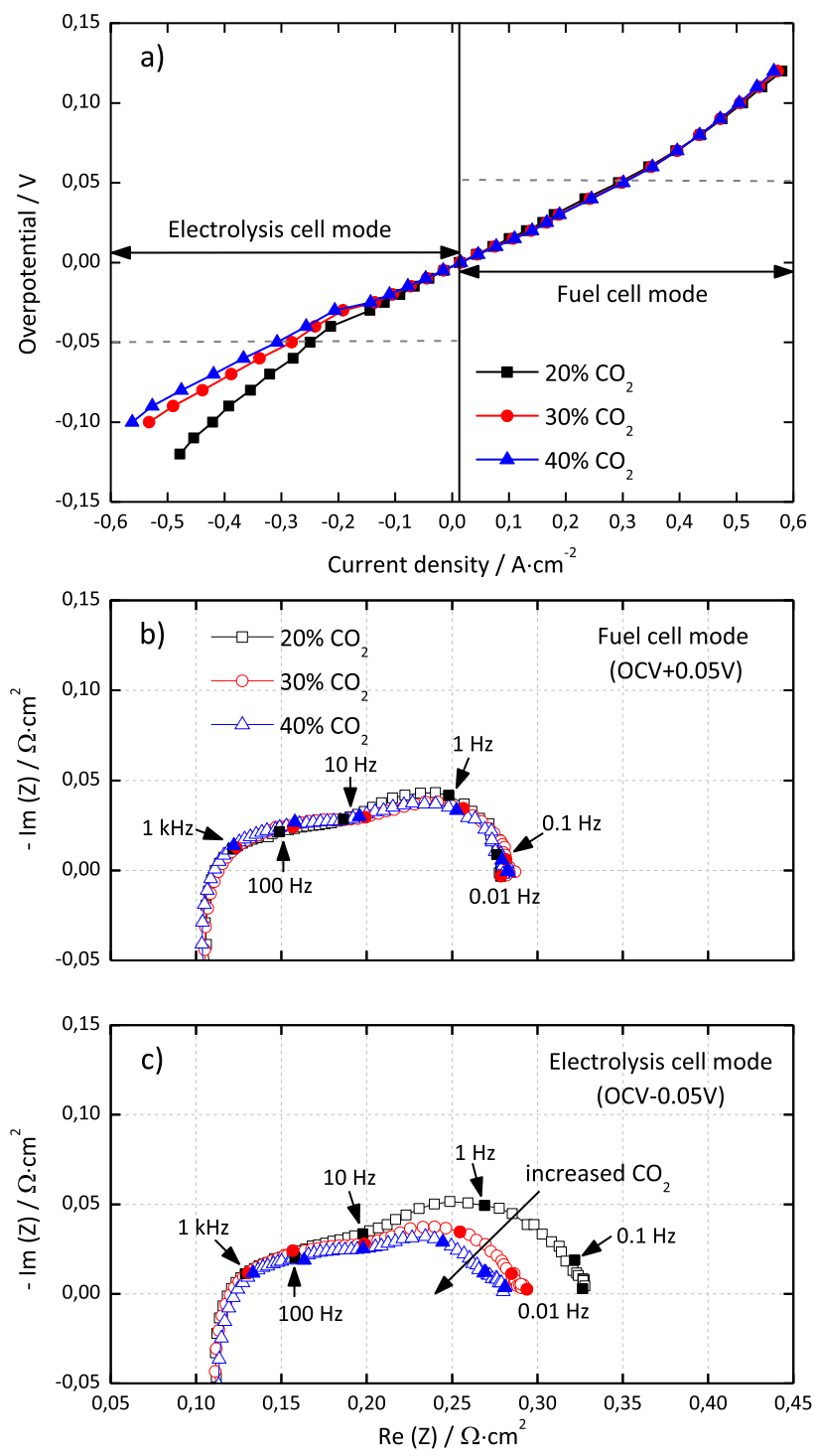

Fig. 6 - The performance of the Ni electrode at $650{ }^{\circ} \mathrm{C}$ at different percentages of $\mathrm{CO}_{2}$. a) iR-corrected polarization curves, b) and c) electrochemical impedance spectra of the $\mathrm{Ni}$ electrode in fuel cell and electrolysis cell modes, respectively. The solid symbols in b) and c) refer to some specific frequencies. 
Table 4 - Analysis of the electrochemical impedance spectra of the $\mathrm{Ni}$ electrode at different $\mathrm{CO}_{2}$ contents in Fig. 6(b and c).

\begin{tabular}{llccc} 
Resistance & Operating modes & $20 \%$ & $30 \%$ & $40 \%$ \\
\hline Ohmic loss & Fuel cell & 0.111 & 0.113 & 0.111 \\
$\left(\Omega \mathrm{cm}^{2}\right)$ & Electrolysis cell & 0.118 & 0.120 & 0.122 \\
Charge-transfer & Fuel cell & 0.075 & 0.082 & 0.084 \\
$\left(\Omega \mathrm{cm}^{2}\right)$ & Electrolysis cell & 0.079 & 0.079 & 0.076 \\
Mass-transfer & Fuel cell & 0.092 & 0.084 & 0.087 \\
$\left(\Omega \cdot \mathrm{cm}^{2}\right)$ & Electrolysis cell & 0.129 & 0.096 & 0.083 \\
\hline
\end{tabular}

charge-transfer (high-frequency part) of the Ni electrode in electrolysis cell mode. On the other hand, the mass-transfer polarization decreased when increasing the amount of $\mathrm{CO}_{2}$. In electrolysis cell mode $\mathrm{CO}_{2}$ is likely to act as a reactant to produce carbonate ions $\left(\mathrm{H}_{2} \mathrm{O}+\mathrm{CO}_{2}+2 e^{-} \rightarrow \mathrm{H}_{2}+\mathrm{CO}_{3}^{2-}\right)$. Additionally, there is still a possibility of electrolysis of $\mathrm{CO}_{2}$ generating $\mathrm{CO}\left(2 \mathrm{CO}_{2}+2 e^{-} \rightarrow \mathrm{CO}+\mathrm{CO}_{3}^{2-}\right)$, even though the kinetics of this reaction on the Ni-based electrode is probably slower than electrolysis of $\mathrm{H}_{2} \mathrm{O}$ producing hydrogen [12]. The $\mathrm{Ni}$ electrode shows similar charge-transfer resistance for $\mathrm{CO}_{2}$ in fuel cell and electrolysis cell modes since the highfrequency arc is almost in the same size. For the lowfrequency arc, the mass-transfer resistance of the Ni electrode is higher in the electrolysis cell mode $\left(0.129 \Omega \mathrm{cm}^{2}\right)$ than in fuel cell mode $\left(0.092 \Omega \mathrm{cm}^{2}\right)$ when only containing $20 \% \mathrm{CO}_{2}$. But increasing $\mathrm{CO}_{2}$ to $40 \%$, it can be seen that the masstransfer resistance is slightly lower in the electrolysis cell $\left(0.083 \Omega \cdot \mathrm{cm}^{2}\right)$ than in the fuel cell mode $\left(0.087 \Omega \cdot \mathrm{cm}^{2}\right)$. It seems that $\mathrm{CO}_{2}$ plays a very complex role in the electrolysis cell mode. For example, $\mathrm{CO}_{2}$ is a reactant when producing carbonate ions $\left(\mathrm{CO}_{3}^{2-}\right)$ or generating $\mathrm{CO}$ gas, and besides that $\mathrm{CO}_{2}$ participates in the reverse water gas shift reaction $\left(\mathrm{CO}+\mathrm{H}_{2} \mathrm{O} \rightleftharpoons \mathrm{CO}_{2}+\mathrm{H}_{2}\right)$ or others.

\section{Electrochemical performance of the NiO oxygen electrode}

The polarization of the $\mathrm{NiO}$ oxygen electrode was investigated in both fuel cell and electrolysis cell modes with gases of 15/

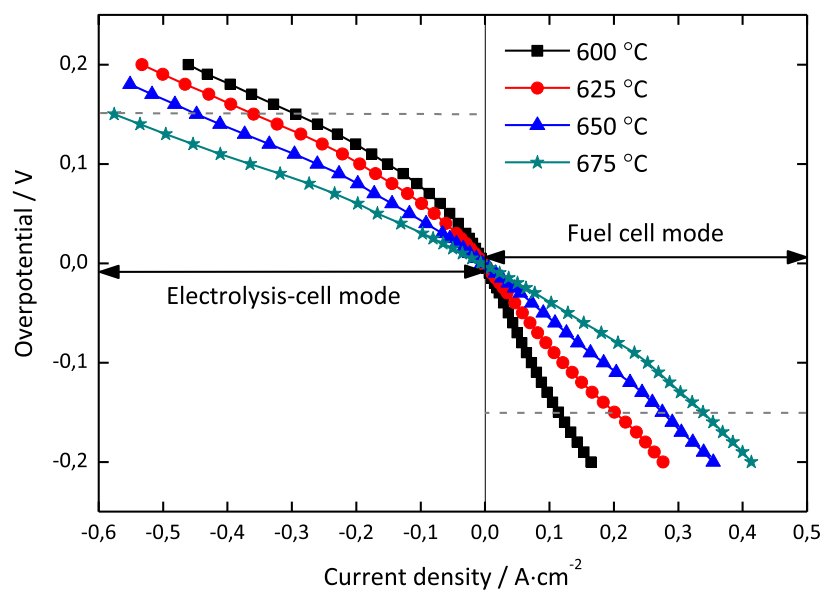

Fig. 7 - iR-corrected polarization curves for the NiO electrode in fuel cell and electrolysis cell modes at operating temperatures from 600 to $675^{\circ} \mathrm{C}$.
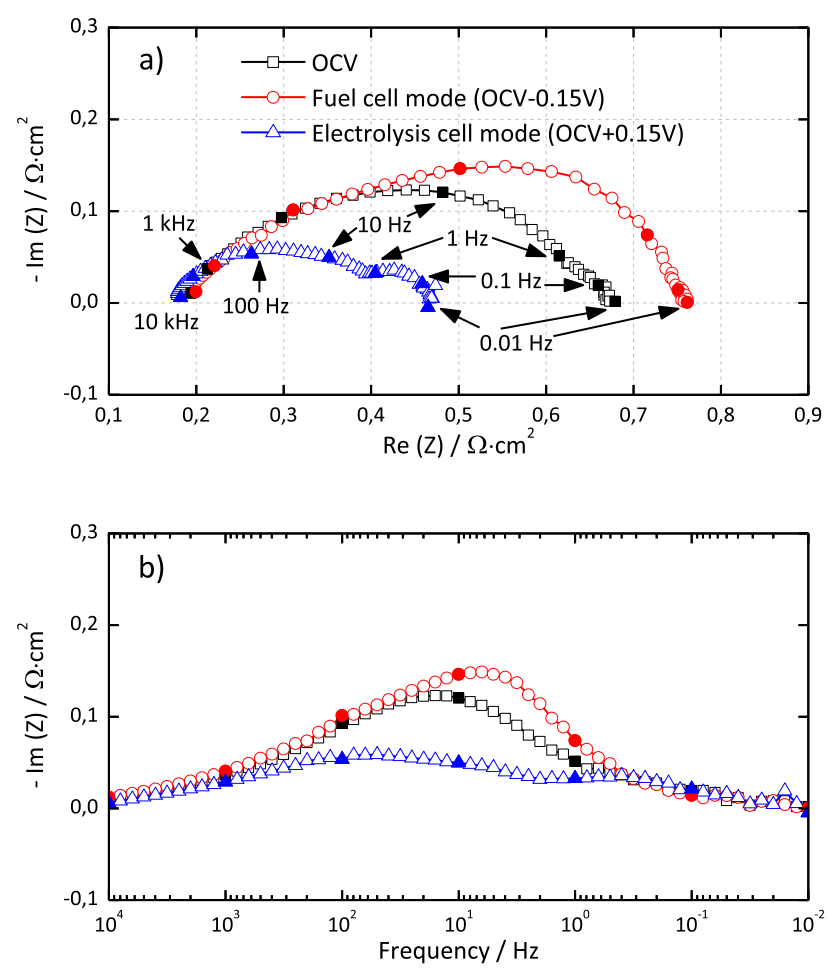

Fig. 8 - Electrochemical impedance spectra of the NiO electrode in $\mathrm{OCV}$, fuel cell and electrolysis cell at $650^{\circ} \mathrm{C}$. a) Nyquist plot and b) Bode plot.

$30 / 55 \% \mathrm{O}_{2} / \mathrm{CO}_{2} / \mathrm{N}_{2}$ at operating temperatures varying from 600 to $675{ }^{\circ} \mathrm{C}$, as shown in Fig. 7. The electrode exhibited asymmetrical behavior between the fuel cell (oxygen reduction: $1 / 2 \mathrm{O}_{2}+\mathrm{CO}_{2}+2 e^{-} \rightarrow \mathrm{CO}_{3}^{2-}$ ) and electrolysis cell modes (oxygen production: $\mathrm{CO}_{3}^{2-} \rightarrow 1 / 2 \mathrm{O}_{2}+\mathrm{CO}_{2}+2 e^{-}$). It can be seen that the electrode polarization loss was much lower in the electrolysis cell mode in this temperature range. Using a constant polarization of $150 \mathrm{mV}$ at $600,625,650$ and $675^{\circ} \mathrm{C}$, the fuel cell current densities were $0.11,0.20,0.28$ and $0.34 \mathrm{~A} \mathrm{~cm}^{-2}$, while the electrolysis cell current densities were $-0.29,-0.36,-0.45$ and $-0.58 \mathrm{~A} \mathrm{~cm}^{-2}$, respectively. Therefore the NiO electrode showed significantly better electrochemical performance as an MCEC anode than as an MCFC cathode. As expected the polarization loss of the $\mathrm{NiO}$ electrode decreased in both operating modes when increasing the temperature.

Fig. 8 shows EIS spectra of the NiO oxygen electrode in three different operating modes at $650{ }^{\circ} \mathrm{C}$. The overpotential versus OCV of $-0.15 \mathrm{~V}$ and $+0.15 \mathrm{~V}$ was applied for the NiO electrode under cathodic polarization (fuel cell) and anodic polarization (electrolysis cell). As shown in Fig. 8(a), the respective electrode impedances of the $\mathrm{NiO}$ electrode were $0.485,0.562$ and $0.283 \Omega \mathrm{cm}^{2}$ in OCV, fuel cell and electrolysis cell modes. The high-frequency and low-frequency arcs in OCV and fuel cell modes are not easily distinguishable. This is in agreement with previous studies $[18,19]$ of $\mathrm{NiO}$ electrodes, in where it was shown that the large kinetic impedance masked the mass-transfer arc. On the other hand two arcs are clearly shown in electrolysis mode; one arc at high- and one at low- frequencies. To fully understand the appearance of the 
impedance spectrum for the NiO electrode further investigations with varying gas compositions and temperatures will be undertaken.

\section{Conclusions}

A molten carbonate cell with state-of-the-art components can be operated both as fuel cell and electrolysis cell. The cell exhibited better electrochemical performance in MCEC mode than in MCFC mode. In spite of the promising performance in MCEC mode, further long-term tests of the cell are still needed to demonstrate the potential viability of the reversible molten carbonate fuel cell.

The Ni hydrogen electrode showed higher polarization loss in electrolysis cell mode than in fuel cell mode at all temperatures and water contents. It is mainly due to the larger masstransfer polarization rather than electrode charge-transfer polarization according to the impedance results. $\mathrm{CO}_{2}$ though has an important impact on the Ni electrode in electrolysis cell mode. When increasing the $\mathrm{CO}_{2}$ content to $40 \%$, the $\mathrm{Ni}$ electrode showed slightly lower polarization in electrolysis cell mode than in fuel cell mode at the same gas composition. That is probably due to several factors, such as $\mathrm{CO}_{2}$ as a reactant for producing electrolyte or generating $\mathrm{CO}$, and also participating in the reverse water gas shift reaction. The NiO oxygen electrode performs much better in MCEC mode. Both the charge-transfer and mass-transfer polarization of the NiO electrode is lower in electrolysis cell mode.

\section{Acknowledgments}

The financial support of the China Scholarship Council (CSC) is appreciated. The cell components were provided by Ansaldo Fuel Cells in Italy.

\section{R E F E R E N C E S}

[1] Ball M, Wietschel M. The future of hydrogen-opportunities and challenges. Int J Hydrogen Energy 2009;34:615-27.

[2] Abbaslou RMM, Mohammadzadeh JSS, Dalai AK. Review on Fischer-Tropsch synthesis in supercritical media. Fuel Process Technol 2009;90:849-56.
[3] Nipattummakul N, Ahmed II, Kerduwan S, Gupta AK. Hydrogen and syngas production from sewage sludge via steam gasification. Int J Hydrogen Energy 2010;35:11738-45.

[4] Tao Y, Nishino H, Ashidate S, Kokubo H, Watanabe M, Uchida $\mathrm{H}$. Polarization properties of $\mathrm{La}_{0.6} \mathrm{Sr}_{0.4} \mathrm{Co}_{0.2} \mathrm{Fe}_{0.8} \mathrm{O}_{3^{-}}$ based double layer-type oxygen electrodes for reversible SOFCs. Electrochim Acta 2009;54:3309-15.

[5] Moreno A, McPhail S, Bove R. International status of molten carbonate fuel cell (MCFC) technology. p. 5. Available at: http://dualibra.com/wp-content/uploads/2011/06/ fuelcellmcfc.pdf; 2008 [accessed June 2013].

[6] Kulkarni A, Giddey S. Materials issues and recent developments in molten carbonate fuel cells. J Solid State Electrochem 2012;16:3123-46.

[7] FuelCell Energy Company, USA. Available at: http://www. fuelcellenergy.com/ [accessed June 2013].

[8] Dönitz W, Erdle E. High-temperature electrolysis of water vapor - status of development and perspectives for application. Int J Hydrogen Energy 1985;10:291-5.

[9] Laguna-Bercero MA. Recent advances in high temperature electrolysis using solid oxide fuel cells: a review. J Power Sources 2012;203:4-16.

[10] Ebbesen SD, Graves C, Mogensen M. Production of synthetic fuels by co-electrolysis of steam and carbon dioxide. Int J Green Energy 2009;6:646-60.

[11] Graves C, Ebbesen SD, Mogensen M. Co-electrolysis of $\mathrm{CO}_{2}$ and $\mathrm{H}_{2} \mathrm{O}$ in solid oxide cells: performance and durability. Solid State Ionics 2011;192:398-403.

[12] Ebbesen SD, Knibbe R, Mogensen M. Co-electrolysis of steam and carbon dioxide in solid oxide cells. J Electrochem Soc 2012;159:F482-9.

[13] Kaplan V, Wachtel E, Gartsman K, Feldman Y, Lubomirsky I. Conversion of $\mathrm{CO}_{2}$ to $\mathrm{CO}$ by electrolysis of molten lithium carbonate. J Electrochem Soc 2010;157:B552-6.

[14] Kaplan V, Wachtel E, Lubomirsky I. Titanium carbide coating of titanium by cathodic deposition from a carbonate melt. J Electrochem Soc 2012;159:E159-61.

[15] Lagergren C. Electrochemical performance of porous MCFC cathodes. Ph.D thesis. Stockholm: Chemical Science and Engineering, KTH; 1997. p. 9.

[16] Lagergren C, Lundblad A, Bergman B. Synthesis and performance of $\mathrm{LiCoO}_{2}$ cathodes for the molten carbonate fuel cell. J Electrochem Soc 1994;141:2959-66.

[17] Yoshikawa M, Bodén A, Sparr M, Lindbergh G. Experimental determination of effective surface area and conductivities in the porous anode of molten carbonate fuel cell. J Power Sources 2006;158:94-102.

[18] Yuh CY, Selman JR. Characterization of fuel cell electrode processes by AC impedance. AIChE J 1988;34:1949-58.

[19] Yuh CY, Selman JR. The polarization of molten carbonate fuel cell electrodes II. Characterization by AC impedance and response to current interruption. J Electrochem Soc 1991;138:3649-56. 